\title{
Regional Election and Covid-19: Evidence in Central Kalimantan
}

\author{
Anyualatha Haridison ${ }^{1}$, Jhon Retei Alfri Sandi ${ }^{2}$, Suprayitno ${ }^{3}$, Imanuel Jaya ${ }^{4}$ \\ ${ }_{1,2,3,4}$ Faculty of Social Science and Political Science, Universitas Palangka Raya, Indonesia \\ a.haridison@fisip.upr.ac.id
}

\section{Abstract}

On December 9, 2020, people in Indonesia, especially in Central Kalimantan, participated in holding regional head elections simultaneously. In the Regional Election (Pilkada) on December 9 in Kalimantan, there were 2 elections, namely the regional head election for the governor and Deputy Governor of Central Kalimantan for the period 2021-2025 and the election for the regional head of the Regent/Deputy Regent for the period 20212025 in East Kotawaringin Regency. The hustle and bustle of implementing the simultaneous regional elections on 9 December 2020 has differences from the previous regional head elections, this is because the implementation of the 9 December 2020 regional elections was held amid the pandemic threat of covid-19 (coronavirus disease -19). Even though it went through a long process, the pros and cons covered the election policy for the simultaneous regions, in the end, the elections were still held on December 9, 2020. Apart from Central Kalimantan, in Indonesia alone, there were around 270 regions that held simultaneous regional elections on 9 December 2020. The study in this paper wants to know how the regional head elections are held in Central Kalimantan, especially in the city of Palangka Raya. This is because Palangka Raya City has a history of the highest confirmed area of Covid-19 transmission. Besides, Palangka Raya as the capital of Central Kalimantan Province is a barometer of seeing the succession of simultaneous regional elections in Central Kalimantan. In its implementation, the Central Kalimantan Pilkada in Palangka Raya went well. The voter turnout in Palangka Raya City reached 63\%. What is unique is that the regional elections in Central Kalimantan have increased participation amid a pandemic compared to the 2015 regional elections which were held in conditions without a pandemic. Even though the overall participation is below the target of the KPU RI, this increase needs to be appreciated.
Keywords

regional election (Plkada); covid-19; pandemic, central Kalimantan

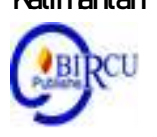

\section{Introduction}

The pandemic of the spread of the coronavirus disease 19 (covid-19) which began to enter Indonesia until the end of 2020 has no signs that it can be overcome shortly. The pandemic that has plagued almost all over the world has caused almost all countries to be overwhelmed in anticipating the rapid spread of the Covid virus. According to Mujani (2020: 159), the Covid-19 outbreak is a global phenomenon that is estimated to have a multidimensional impact on the lives of the world community. Countries around the world vary in their response to a policy as well as their performance against this pandemic. The 
policies or steps were taken by each country in dealing with Covid-19 certainly have an impact and are at risk for all aspects of human life (Saleh \& Mujahiddin, 2020).

Since the president of the Republic of Indonesia, President Joko Widodo announced that on March 2, 2020, Covid-19 had entered Indonesia, so far there have been no signs that things are getting better from the spread of the virus. The virus has even spread to 34 provinces in Indonesia so quickly. The government has made various efforts to reduce the rate of transmission of Covid-19, starting from social distancing, work from home (WFH) and even justice operations in various regions to educate the public in implementing health protocols in their daily activities.

The spread of covid-19, which has not shown any signs of improvement until the end of 2020, affects all government policies. The spread of covid-19 that is so fast and uncontrollable does not only affect public health, but also social, economic, religious, and so on. The pandemic has indeed caused several negative impacts on the whole of the world, but several countries have been able to rise and suppress the spread of the Covid-19 Pandemic. The keys of a country in overcoming this crisis are seriousness, prioritizing the interests of the people, and optimism. Efforts to deal with the crisis due to the Covid-19 pandemic cannot be separated from politics must be directed at positive things that can help the country deal with the pandemic, not the other way around (Bustikova \& Babos, 2020).

The Indonesian government programs that were initiated at the beginning of the year have almost all undergone revision amid the continued rampant Covid-19. One of the pros and cons during the Covid-19 pandemic was the continued implementation of the simultaneous regional head elections on December 9, 2020. After experiencing a delay, which was originally planned to be held in September 2020, finally carried out on December 9, 2020, still with the pros. and the cons.

General Election (Pemilu), be it the election of president/vice president, Legislative Election or regional head elections both at the provincial or city level is known as the people's party (Nugraha et al., 2015). The term the people's party is certainly an illustration of how elections and regional head elections are considered part of a process that is fun, joyful and awaited by the people who carry it out. However, under normal conditions, of course, the people's party has a different nuance to the regional elections which were held on 9 December 2020, this is because the simultaneous regional elections were held during the Covid -19 pandemic. Pros and cons especially addressed to the General Election Commission (KPU), which continued to schedule the simultaneous regional elections in 2020, came to the public at that time.

With various pro contracts to continue the implementation of regional elections simultaneously in a pandemic, regional head elections are a form of the implementation of people's sovereignty and democracy in Indonesia. Because one manifestation of the people's sovereignty in Indonesia so far is manifested through the holding of elections to elect people's representatives in the legislature, regional heads, or democratic presidents. The long journey of democracy in the form of democratic elections in Indonesia began with a period of political transition after the 1998 Reformation. The end of the New Order era changed to a reformation era that changed the democratic order in Indonesia to this day, both at the central and regional levels.

Ibnu Tricahyo (2009) Defining General Election is an instrument to realize people's sovereignty which aims to form a legitimate government and a means of articulating the aspirations and interests of the people. The international standard for democratic elections stipulates a minimum of 8 (eight) principles that must be developed in every election activity, namely: (1) Periodic Elections, namely elections must be held at regular intervals 
as stipulated in law; (2) Genuine Elections, which is held in a conducive socio-political environment, where human freedoms are upheld and political pluralism can grow; (3) Free Elections, namely free elections; (4) Fair Elections, namely elections that are able to guarantee fair contestation and uphold equality; (5) Universal Suffrage, which must be able to guarantee the right to vote and be elected by all citizens who meet the requirements (elible) according to law; (6) Equal Suffrage, ie every citizen has one vote and each vote is graded with the same value, namely one person, one vote, one value (one man, one vote, one value); (7) Voting by Secret Ballot, namely that the election administration must be able to guarantee the confidentiality of the voters' choices; (8) Honest Counting and Reporting of Resulity, namely the election organizers when carrying out the task of counting votes, the tabulation of votes must act professionally, impartially, efficiently and accurately (Afina, 2020)

The existence of a Government Regulation instead of Law (Perpu) Number 02 of 2020 issued by President Joko Widodo is the basis for the continuation of the stages of regional head elections simultaneously considering that there is no guarantee of the time when the pandemic will end so that the Perpu is one of the bases for the implementation of the elections on December 9, 2020, continues. This is because the Pilkada is an important momentum in choosing a definitive leader in the region who is expected to be able to become a new spirit and also innovation in various policies for the benefit of society. The simultaneous Regional Head Election on 9 December 2020 was attended by 270 Regions covering several provincial, district and city levels (Haridison, 2016; Sandi et al., 2020).

In the Central Kalimantan regional head election, December 9, 2020, two candidates competed in the regional election. The candidate is candidate number 1, namely the pair Ben Brahim-Ujang Iskandar who are promoted and supported by 3 political parties, namely the Democratic party, the Gerindra party and the Hanura party with a total number of seats in the DPRD as many as 12 seats. Meanwhile, the pair Sugianto Sabran-Edy Pratowo were carried and supported by 33 seats with details of the supporting and supporting parties, namely the PDI Perjuangan party, the Golkar Party, the Nasdem Party, the PPP Party, the PKB party, the PKS party, the Perindo party, and the PAN party. According to Sandi \& Suprayitno (2020), The nuances of regional election contestation amid the threat of the Covid-19 pandemic and the handling steps in Central Kalimantan are relatively quite prominent. At the supra political structure level, the provincial government (executive and legislative) develops contestation of views and policy execution which begins with the process of rationalizing and refining the 2020 Central Kalimantan Regional Budget.

\section{Review of Literature}

Implementation of Democratic Regional Head Elections During the Covid-19 Pandemic

Indonesia is one of the countries that applies a democratic system. As a country that adheres to a democratic system, elections in Indonesia that apply one person, one vote, one post-reform value were first applied directly to the 2004 presidential/vice presidential elections. With the existence of elections, democracy is considered a system that guarantees citizens' freedom. the state is realized through the absorption of votes as a form of broad public participation and accommodating the interests of the people.

Ginsburg \& Huq (2018) in Landman Dan Splendore (2020:2) elections are a mainstay feature and 'basic predicate' of democracy. Scholarly speaking, Indonesia has been undergoing electoral democracy in the last two decades since the fall of the Suharto regime in 1998, with five legislative elections since 1999-and four presidential elections 
from 2004 - to the 2019 general election when legislative and presidential elections were held concurrently for the first time (Budi \& Pamungkas, 2020). According to John Forejohn and Pasquale Pasquino in Gafar (2013: 63) said that democracy and the rule of law are formed into two different institutions, but both are always in contact with each other and there can be tension because democratic institutions and legal institutions can also act as law-formers. When legal institutions succeed in gaining broad authority to regulate and organize social interactions, the role of democratic institutions will be limited. Conversely, when the parliament can claim the highest authority to make the rule of law, the legal institution is demoted to obey as the agent of the democratic institution. According to Syamsudin Haris, an election is a form of political education for the people, which is direct, open, and mass, which is expected to be able to educate political understanding and increase public awareness of democracy.

With this direct election, Indonesia is predicted to become a successful country as a democracy. This is due to the large population, but democracy can be carried out well in Indonesia. According to Huda (2010), democracy is the best principle and system in the political system and state administration. In a democracy, one of the impacts in Indonesia is the existence of Regional Head Elections which provide flexibility for regions in choosing candidates for leaders in their regions. The simultaneous regional head election is an effort to create local accountability, political equality and local responsiveness so that local level democratization is closely related to the level of participation and power relations built based on the implementation of the principle of people's sovereignty. Also, the results of regional head elections are expected to be able to bring people to better social, political and economic conditions. The election of a good regional head will give birth to good governance. Regional head elections that are carried out in a more professional, democratic manner will have a real impact on political change (Arifulloh, 2015).

Nasdik (2016) in Hadi Prabowo et al. (2020) states that elections are one of the characteristics that must exist in a democratic country. The election is an important means for society in the life of a state which is carried out by choosing representatives who in turn will control the wheels of government. The election results were held in an atmosphere of openness with freedom of opinion and freedom of association considered quite accurate in reflecting the aspirations and participation of the community. According to Asshidiqqie (2006) the importance of holding regular general elections is due to several reasons including the following: (1) the opinion or aspirations of the people tend to change from time to time; (2) conditions of community life that can also change; (3) additional population and adult people who can exercise their voting rights; (4) is used to ensure leadership regulation in both the executive and legislative branches.

Socialization is a process of learning to a person to understand and have awareness of the role properly in the community. So socialization is also often said as the process of education to better know something that has not been known someone in social life, such as knowing the role, norms and values in the community to adapt and interact among human beings (Amrizal et al, 2018). Marulak Pardede in Antari, Putu Eva Ditayani (2018:93) reveals that there are several reasons for the importance of implementing elections in a country, namely: (1) In the framework of exercising people's sovereignty; (2) To elect people's representatives; (3) To ensure or at least update the agreement on the part of the citizens of the country; (4) Influencing citizen behaviour; (5) Educate rulers to increasingly rely on agreement from the people rather than coercion to maintain their legitimacy. 
According to Austin Ranney in Syafhendry (2017), there are eight main criteria for a democratic election, including, First, The existence of general voting rights (active and passive) means that in executive and legislative elections every citizen has the same opportunity in the public space to vote and be elected. Active voting rights are the rights of citizens who have fulfilled the requirements to elect representatives in the DPR, DPD, DPRD, President-Vice President, and Regional heads, namely 17 years of age or married/married, not disturbed by memory, not revoked of their voting rights, not is currently undergoing a prison sentence, registered in the Permanent Voters List (DPT). What is meant by passive suffrage is the right of citizens who have met the requirements to be elected as members of the DPR and DPRD. Second, Equal voting weight means that there is an obligation to guarantee that the votes of each voter are given the same weight in the election. All voters have the same percentage weight per person regardless of position and position. Third, the availability of choices of candidates from different ideological backgrounds. The purpose of this criterion is the availability of a real election and its visible difference with other choices wherein essence it requires more than one choice, then the choice can be very simple such as the difference between two or more candidates or a more complicated difference between two or more different political lines/work programs to the difference between two or more ideologies. In elections, of course, several parties have different ideological bases, and the candidates promoted by these parties will follow the rules set out in their party. This is what then makes the election not only a competition between parties and candidates, but there is also political and ideological competition.

Fourth, Freedom for the people to nominate certain figures who are seen as capable of creating prosperity and justice. The freedom to choose comes from the people themselves so that the principle of freedom also implies the importance of freedom of association. It is from these organizations that groups of people interact to propose the best alternative for realizing the welfare of their nation. The point is that freedom of association contains the principle of freedom to appoint candidates for representatives of the people in which way candidates who have an important meaning can be guaranteed in the election. Fifth, Equal campaign rights; elections are a means to attract as many masses as possible, where candidates introduce themselves and socialize their work programs. Therefore, all candidates are given equal rights or equal opportunities to a campaign, because the campaign also requires freedom of communication and information disclosure. Sixth, Freedom to vote; voters can make their choice freely, meaning that every citizen who chooses is free to make his choice without pressure and coercion from anyone, and in exercising his rights every citizen is guaranteed his security so that he can vote according to his conscience and interests. Seventh, Honesty in counting votes; honesty and openness are needed in the vote-counting process, because the entire electoral process will be in vain if there is no honesty in it, and fraud in vote counting will have very fatal consequences, namely the failure of the efforts made by the people to get their representatives into the representative body people.

Finally, Eighth, Periodic administration A ruler may not act at will in determining the timing of the election administration, in the sense that the election administration may not be proposed or postponed on its own accord. Where in general, elections are held every five years by the General Election Commission (KPU). With the Covid-19 pandemic that has yet to show signs of improvement, the implementation of the regional elections on 9 December 2020 is a challenge that is not easy. As part of choosing leaders in the regions, regional elections are of course one solution. With the presence of leaders in the regions who were elected in the simultaneous regional elections on December 9, 2020, of course, it 
is hoped that the handling of Covid-19 in the regions can be more optimal. Local leadership has significant meaning for the handling of the Covid-19 pandemic. Regional leaders have the opportunity to know more about the conditions of various pandemic handling problems in the regions. The policies of these regional leaders also have the opportunity to be directly felt by residents at the local level. The impact on the responses and policies felt by citizens has also led to public assessments of the leadership performance of regional heads. In other words, their leadership during a pandemic, for one thing, had an impact on their political popularity. This public assessment can raise the trust of citizens in regional leaders in dealing with various problems. It is not impossible, in such performances, regional leaders will receive public assessments that can encourage them to enter the leadership phase at the national level (Hanafi, 2020).

\section{Research Methods}

This research uses a qualitative approach. To achieve the purpose of this writing, data were collected by conducting interviews with candidate pairs, the General Election Commission of Central Kalimantan Province, the voting community, and related stakeholders. This study also uses a survey of the voters to obtain responses regarding the regional elections in the pandemic era. data collection was carried out from March June 2020 to January 2021.

\section{Results and Discussion}

The Covid-19 pandemic outbreak which is a global threat affects all activities of human life on earth, especially in Indonesia. Various government policies have been made to minimize and combat the transmission of this virus, but until now it has not been eliminated from the face of the earth. The Indonesian government itself has since confirmed that the covid-19 virus has entered Indonesia, making various policies including PSBB (large-scale social restrictions), restrictions for foreigners who want to enter Indonesia, justice operations, massive campaigns about 3M: wearing Masks, washing hands, and keeping distance and so on, but every day there is still an increase confirmed by Covid-19.

With the existence of Covid-19, regional head elections in Central Kalimantan, especially in Palangka Raya City, were carried out strictly on health protocols. The KPU of Central Kalimantan province and KPU of Palangka Raya City as the organizer of the regional election in Central Kalimantan work hand in hand so that the implementation can run smoothly. Although the implementation of the elections in the middle of the pandemic was taking place, respondents in Palangka Raya City stated that they were sure that the implementation of the Pilkada could proceed as it should. Respondents in this study were 208 respondents representing 5 districts in Palangka Raya City, including Pahandut, Jekan Raya, Rakumpit, Sebangau, and Bukit Batu districts. The selected respondents are those who are registered as DPT (Permanent Voters List) in their respective regions. Regarding the implementation of the 9 December 2020 Pilkada with the question indicator "Administrators and the Government can implement and ensure standard health protocols are implemented properly in the 2020 General Election activities" obtained the following data: 
Table 1. The results of the questionnaire

\begin{tabular}{|c|c|c|}
\hline No. & Respondents & $(\%)$ \\
\hline 1 & Strongly agree & 22.1 \\
\hline 2 & Agree & 50.5 \\
\hline 3 & Disagree & 13 \\
\hline 4 & Strongly Disagree & 2.9 \\
\hline 5 & Do not know & 11.5 \\
\hline
\end{tabular}

Source: processed data, 2020.

From the results of the questionnaire above, it is concluded that the people in Palangka Raya City have confidence in the election organizers and the government that the Central Kalimantan elections on December 9, 2020, in a pandemic can be carried out and guaranteed to comply with the prescribed health protocol. Pilkada stages have been carried out well in Central Kalimantan. Even amid a pandemic, the organizers can carry out the stages in stages.

\subsection{Candidate Pair Campaign Stages}

The Campaign Period is a period where the pair of candidates can introduce their vision and mission, work programs and promises if they are elected as leaders. The Covid19 pandemic has changed the campaign strategy for the 9 December 2020 regional elections for Central Kalimantan, especially in Palangka Raya. Based on KPU Regulation Number 13 of 2020 concerning the implementation of the follow-up Pilkada, candidate pairs who are contesting the elections are still allowed to hold limited meetings and dialogues. The campaign in Palangka Raya from each candidate is still considered accessible by the people in Palangka Raya City. Of 208 respondents, 59.1\% of respondents agreed that the implementation of the elections in Central Kalimantan was easily accessible. There are two campaigns carried out by candidate pairs, namely offline and online. Candidate pairs conduct limited meetings offline with the community and their campaign team as well as through banners, pamphlets and billboards as well as news in print media. Meanwhile, the online campaign conducted by candidate pairs is through Campaigns on Television, Radio, online news and Social Media such as Facebook, Instagram, Whatsapp, Youtube, Tiktok.

Most of the people in Palangka Raya City stated that during the Covid-19 pandemic, the candidate pair campaign method was virtually considered quite effective. The results of their responses are as follows:

Table 2. The responses of the respondents

\begin{tabular}{|c|c|c|}
\hline No. & Respondents & $(\%)$ \\
\hline 1 & Strongly agree & 24,1 \\
\hline 2 & Agree & 44,7 \\
\hline 3 & Disagree & 24,5 \\
\hline 4 & Strongly Disagree & 1,9 \\
\hline 5 & Do not know & 4,8 \\
\hline
\end{tabular}

Source: processed data, 2020.

From the responses of the respondents above, it can be concluded that the campaign model carried out during the pandemic with the virtual method received positive appreciation from the public. This means that the innovation made by candidate pairs using virtual media in the campaign is considered quite effective. However, this is certainly 
effective for regions that are indeed supported by internet facilities and also other supporters. For areas that are not supported by adequate internet facilities, virtual campaigns need to be considered. The absence of serious violations related to the campaign process in Palangka Raya City is proof that the candidate pairs for governor and deputy governor of Central Kalimantan obeyed the KPU's appeal and certainly no new covid-19 cluster after the election is an indicator of the success of the elections in Central Kalimantan, especially Palangka City. One of the main events in the election process is the campaign period.

\subsection{Debate Stages}

The Pilkada Debate which was held during the Covid-19 Pandemic was different from the previous Pilkada situation. Previously, there were no strict rules in the health protocol, but in this debate, all pairs of candidates and their supporters are obliged to comply with the health protocol. Candidates and supporters must wear masks, keep their distance and reduce crowds during the debate. Even though in a pandemic, the Central Kalimantan KPU held an offline debate which could be accessed on television ( 2 debates on local television and 1 debate on National Television.) In the implementation of the debate, in the first stage, the two pairs of candidates were able to follow the debate process well. However, in stages 2 and 3 one of the candidates was confirmed positive for Covid19 so that in stages 2 and 3 one of the candidate pairs only sent a representative for debate. With this, there should be innovations from the KPU, for example, pairs of candidates who did not participate in the debate were facilitated to greet via virtual, but this was not done. The pandemic should not limit the access and tone of innovation made by the Central Kalimantan KPU so that each pair of candidates can participate in the debate, even if not directly.

\subsection{Election Stages}

In general, the election process in Central Kalimantan, especially in Palangka Raya City, ran smoothly. Based on the KPU's official website, which was updated on December 21, 2020, data on candidate pairs in Central Kalimantan, namely pair number 1 (pair Ben Brahim - Ujang Iskandar) received 48.4\% (487,883 votes) and serial number pairs 2 (pair Sugianto Sabran-Edy Pratowo as much as $51.6 \%(518,260)$. In general, voter participation in Central Kalimantan is 53.86\%. Meanwhile, in Palangka Raya City, voter participation is 109,770 people with the number of registered voters in the DPT as many as 185611 people. Even though the implementation of the Central Kalimantan regional election is running smoothly, pair number 1 (pair Ben Brahim - Ujang Iskandar) is currently filing a lawsuit at the Constitutional Court, which is scheduled to have its first trial on January 18, 2021. With the election results that are not yet final -Each pair of candidates prepares their best legal experts and proves that their votes can be accounted for at the MK trial. The implementation of the Pilkada in Central Kalimantan is over. Then each pair of candidates should respect whoever the winner is and begin to knit back consolidation to jointly build the river basin of Central Kalimantan.

\section{Conclusion}

From the article above, it can be concluded that the implementation of the simultaneous regional elections on December 92020 in Central Kalimantan, especially in the city of Palangka Raya, ran smoothly even though it was carried out during the Covid19 pandemic. The condition of Covid-19 did not affect the implementation of regional 
elections in Central Kalimantan, especially the city of Palangka Raya. Stages carried out by adhering to strict health protocols were able to create a safe and peaceful regional election in Central Kalimantan. Innovations are needed for the holding of similar regional elections if the pandemic continues so as not to reduce the quality of future elections. The condition of Covid-19 did not affect the implementation of the elections in Central Kalimantan, especially the city of Palangka Raya, because the processes in the elections could still be carried out based on strict health protocols.

\section{References}

Afina, Nabila Amrie. 2020. Peran Bawaslu Kabupaten Kebumen Mencegah Politik Uang di Desa Anti Politik Uang Kabupaten Kebumen Perspektif Teori Al-Hisbah. IAIN Purwokerto

Amrizal, D., et al. (2018). The Role of General Election Commission (KPU) in Increasing Voters' Participation in Langkat, Medan, Indonesia. Budapest International Research and Critics Institute-Journal (BIRCI-Journal), P. 13-24.

Antari, Putu Eva Ditayani. 2018. Interpretasi Demokrasi Dalam Sistem Mekanis Terbuka Pemilihan Umum di Indonesia. Jurnal Panorama Hukum. 3(1). 87-104

Asshiddiqie, Jimly. 2006. Pengantar Ilmu Hukum Tata Negara, Jakarta: Sekertariat Jenderal dan Kepaniteraan Mahkamah Konstitusi

2006. Konstitusi dan Konstitusionalisme Indonesia, Jakarta: Sekretariat Jenderal dan Kepaniteraan Mahkamah Konstitusi RI.

Budi, A., \& Warih Aji Pamungkas. 2020. Partisanship in Crisis: Public Response to Covid19 Pandemi in Indonesia. JSP "Jurnal Ilmu Sosial dan Ilmu Politik". 24(1). 15-32

Bustikova, L., \& Babos, P. (2020). Best in Covid: Populists in the time of pandemi. Politics and Governance, 8(4), 496-508.

Gaffar, Janedjri M.2013. Demokrasi dan Pemilu di Indonesia. Jakarta: Konstitusi Press.

Hanafi, Imawan Ridho dkk. 2020. Kepemimpinan Lokal Di Masa Pandemi Covid-19: Respons, Kebijakan, Dan Panggung Elektoral. Jurnal Penelitian Politik-LIPI. 17(2).

Haris, Syamsudin. 1998. Menggugat Pemilihan Umum Orde Baru. Jakarta: Yayasan Obor Indonesia

Haridison, Anyualatha. 2016. Strategi Pengawasan Pemilu: Studi Pemilihan Gubernur dan Wakil Gubernur Provinsi Kalimantan Tengah. Yogyakarta: Aswaja Pressindo.

Huda, Ni'matul. 2010. Hukum Tata Negara Indonesia. Jakarta : Raja Grafindo Persada

Mujani, Saiful. 2020. Asesmen Publik Atas Kinerja Pemerintah Indonesia Menangani Wabah Covid-19: Sebuah Penjelasan Ekonomi Politik. Jurnal Penelitian Politik LIPI. 17(2).

Nugraha, D., Alam, M. D. S., \& Haridison, A. (2015). Peran Komisi Pemilihan Umum Kabupaten Murung Raya dalam Meningkatkan Partisipasi Politik Masyarakat di Kecamatan Murung Kabupaten Murung Raya (Studi Kasus dalam Pemilihan Umum Presiden dan Wakil Presiden 2014). Journal Ilmu Sosial, Politik dan Pemerintahan, 4(1), 1-28.

Prabowo, Hadi., Wirman Syafri \& Juanda. 2020. Pandemi At The Polls: Preparement And Arrangement Of Indonesian Regional The Election In The Midst Of Covid-19. International Journal Of Management (IJM). 11(12). 2189-2199

Syafhendry. 2017. Makna Pencoblosan Dalam Pemilihan Umum. Jurnal Ilmu Politik dan Komunikasi. VII (I)

Saleh, Arifin \& Mujahiddin. 2020. Challenges and Opportunities for Community Empowerment Practices in Indonesia during the Covid-19 Pandemic through 
Strengthening the Role of Higher Education. Budapest International Research and Critics Institute (BIRCI-Journal): Humanities and Social Sciences. 3(2). 1105-1113

Sandi, J. R. A., Suprayitno, S., \& Imanuel Jaya (2020). Public Perception of the Implementation of Simultaneous Regional Head Election 2020 during Covid-19 Pandemi in Palangka Raya Regency. Budapest International Research and Critics Institute (BIRCI-Journal): Humanities and Social Sciences. 3(4). 3333-3340.

Sandi, J.R.A \& Suprayitno. (2020). Fenomena Pengawasan Pemilihan Kepala Daerah Di Kalimantan Tengahmasapandemi Covid-19. Jurnal Politik Pemerintahan Dharma Praja. 13(1).

Tricahyo, Ibnu. 2009. Reformasi Pemilu : menuju pemisahan pemilu nasional dan lokal. Malang : In - Trans Publish

Todd Landman \& Luca Di Gennaro Splendore (2020). Pandemic democracy: elections and COVID-19, Journal of Risk Research, 23:7-8, 1060-1066, DOI: 10.1080/13669877.2020.1765003

Undang-Undang Dasar Negara Republik Indonesia Tahun 1945. 